\title{
微細領域での接着解析技術の進歩 \\ Progress of Adhesion Analysis in Nano-microscale
}

\section{1. 微細固体および微細領域の付着特性}

近年, ナノテクノロジーの進歩に伴い, バイオチップ, マイクロ・ナノマシン, フォトニクスデバイスに代表さ れる微細デバイスの耐久性および構造信頼性が重要視さ れてきている。特に,これらのデバイスの産業化および 実用化段階において, 微細領域での接着性の確保および 解析技術の確立か必須となる。一方,ナノスケールにお ける凝集固体の基本的性質として，固体内部の凝集的な 効果よりあ表面的特性がクローズアップされてくる。ま た，マクロな視点では無視できた接着要因が, 微細領域 では支配的な要因となるケースが見られる。これらの点 は, 表面および界面特性が大きく寄与する接着科学にお いて, 微細領域における重要な要因として位置づけられ る。例として, 図 1 に線幅 $60 \mathrm{~nm}$ の微細加工用のレジス トパターンを示している。パターン表面には $10 〜 30 \mathrm{~nm}$ サイズの高分子集合体が隆起している様子が確認できる。 この表面特性は, レジストパターンと基板界面との接触 面積および相互作用などの付着性要因に大きく影響する。 これらは, 数 10 ミクロン以上のマクロなサイズのレジ ストパターンでは注目されなかった点である。

通常の剥離試験では, 図 2 (a)のように, 荷重点之剥 離開始点が比較的離れているケースが多い。すなわち, 接着層および被着体の凝集力によって, 剥離荷重が剥離 面まで伝達されている。よって, 接着層の変形や凝集破 壊等によって，伝達されるェネルギーは消費されてし まう恐れがある。結果として, 測定された剥離強度と真 の付着力とが一致しない問題が生じることとなる。し

\footnotetext{
*長岡技術科学大学電気系

新湼県長風市上富岡町 1603-1 于 940-2188

Nagaoka University of Technology

1603-1, Kamitomioka-cho, Nagaoka, Niigata 940-2188, Japan
}

河合 晃 ${ }^{*}$

Akira KAWAI かし，図2(b) のように，付着物がナノスケールサイス になると, 荷重点と剥離面が極めて接近するため, 測定 された破壊強度は本質的な剥離特性を示すこととなる。 よって,ナノスケールの付着測定では, 接着層の凝集性 に依存しない付着測定（界面の接着強度測定）が可能に なる。

前述のように,ナノスケールにおいては, 固体の凝集 性よりあ表面特性がさらにクローズアップされる。3 次 元形状においては, 縮細化に伴って固体の表面特性が強 調される。実際に，図 3 に，その一例を示している。 $1 \mu \mathrm{m}$ 径以下の PSL 微粒子の凝集体では, 表面間引力 により複数の PSL が付着した場合, 自らの形状変形を 生じさせて付着していることがわかる。

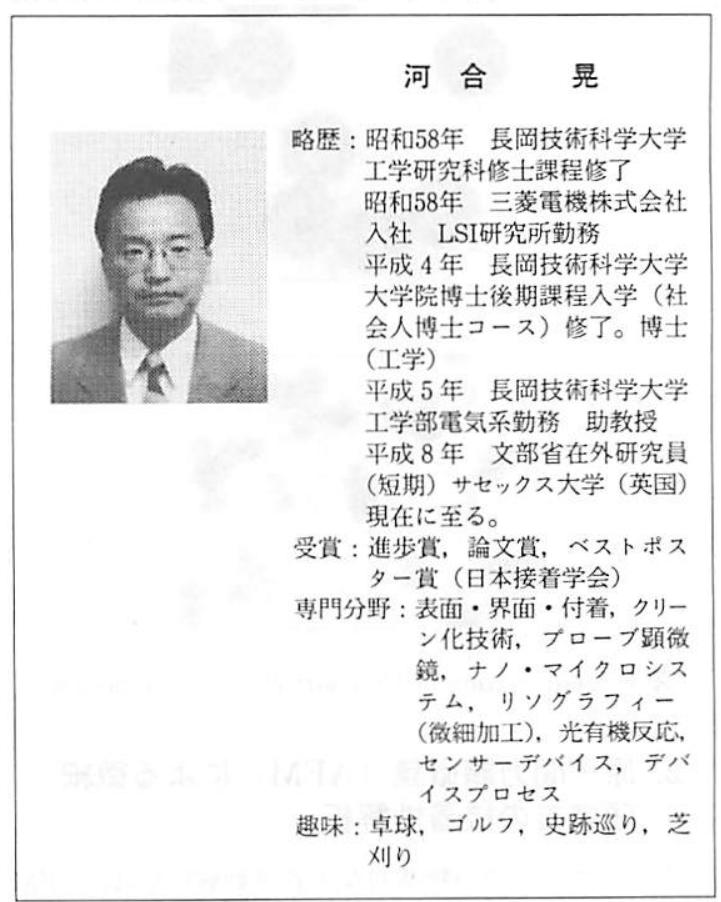




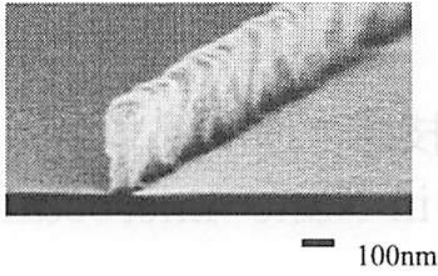

(a ) SEM image

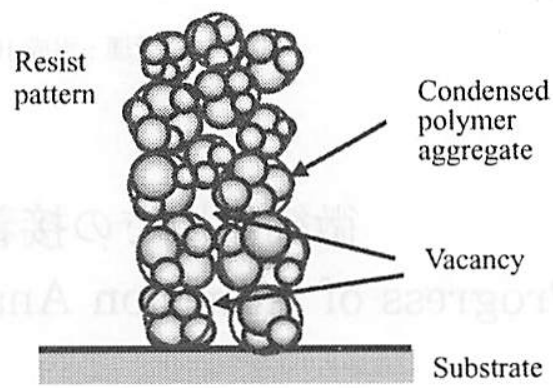

(b) Condensation model

図 1 Resist micro pattern of $60 \mathrm{~nm}$ width.

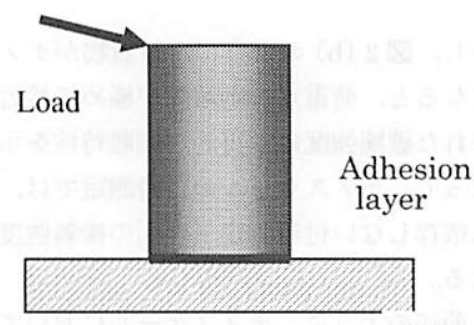

Substrate

(a) Macro scale

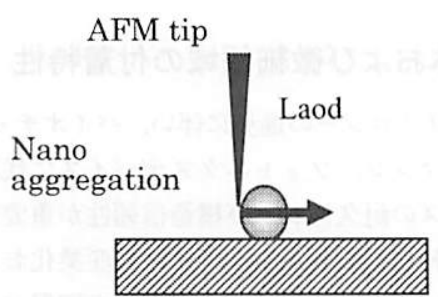

(b) Nanoscale

図 2 Peeling method in micro and nano scale.

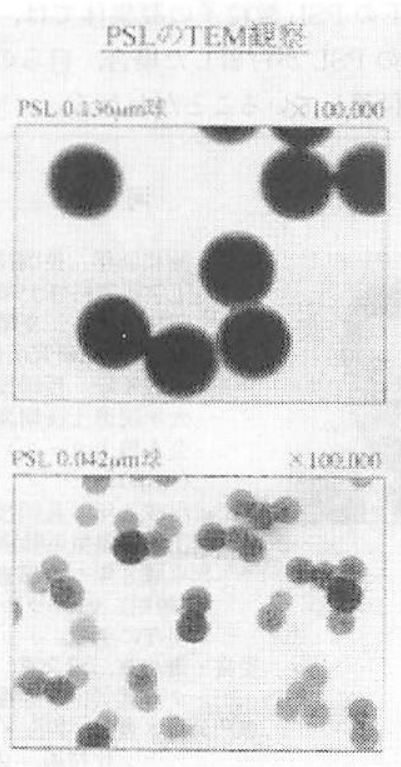

図 3 Deformation of PSL particle due to adhesion.

\section{2. 原子間力顕微鏡 (AFM) による微細 領域での接着性解析}

ナノスケールでの特徴的な接着挙動解析には, AFM
が有効である。筆者は，ナノスケールにおける様々な形 状の微細固体の付着性および疑集性を解析している。 (DPAT 法: Direct peeling with atomic force microscope tip）また, AFM を用いることにより, 微細構造 内の特定の位置に荷重を加えて, 表面硬化層, およびヤ ング率や内部空孔などを解析することができる。

\section{1 相互作用力解析}

AFM を用いることにより, 付着力の要素となる表面 間相互作用力を実測することができる。特に、レナード ポテンシャル型の相互作用曲線を局所的に測定すること ができる。図 4 は, AFM の微細探針の先端にエポキシ 系接着剤をコートし，被着体となる基板表面での相互作 用力を測定した結果である。探針先端が基板表面に近 づくことより, 約 15〜20nm から引力が作用し, 1〜 $2 \mathrm{~nm}$ 付近で最大引力点を経て斥力領域になり, 最終的 に基板之接触する。この最大引力点で力は釣り合うため, この状態がエポキシ系接着剤と被着体との付着性との要 因となっている。しかし，実際の接着表面では表面凹凸 があり, 局所的に相互作用距離が異なり, 複雑な挙動を 示す。

\section{2 マニピュレーション}

前述のように, $100 \mathrm{~nm}$ 以下の微細領域になれば, 凝 集性の比較的低い高分子固体は, 図 1 のようなナノスケー 


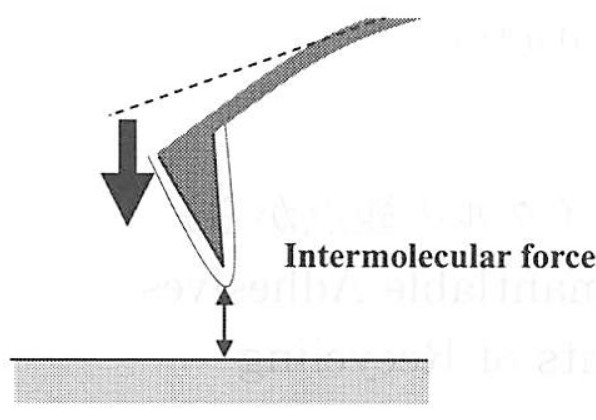

(a) Interaction analysis

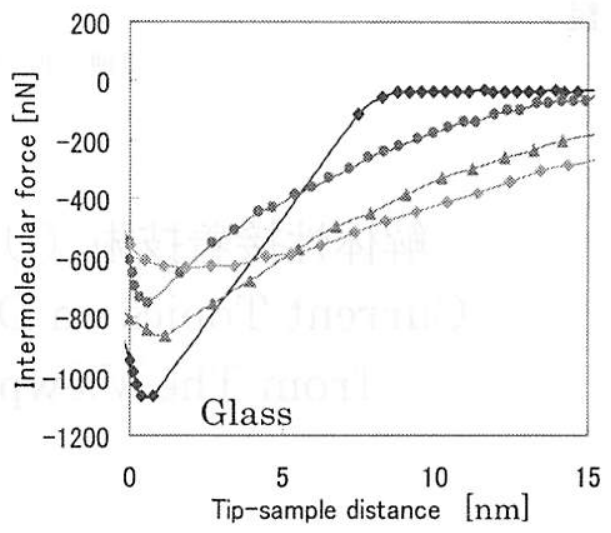

(b) Interaction curve

図 4 Interaction curve between epoxy resin and substrate.
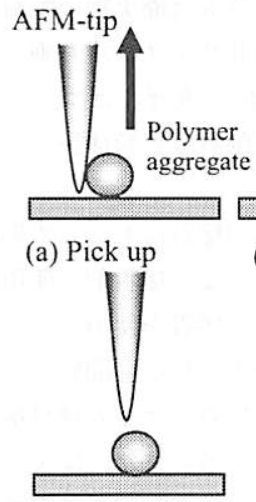

(d) Imaging

図 5 AFM manipulation

ルの高分子集合体の凝集体を構成する。これらの高分子 固体は, $\mathrm{AFM}$ を用いたマニピュレーション技術により， 個々の高分子集合体に分離することができる。（図 5, 図 6）よって，高分子集合体は，凝集性を有した微粒子 として取り扱うことができる。また，高分子集合体の分 離に要した力を実測することで, 高分子固体全体の凝集 性及び界面の付着性を設計できる。

\section{3. まとめ}

微細固体および微細領域での付着現象および解析手法 について述べた。特に,ナノスケールにおける AFMの

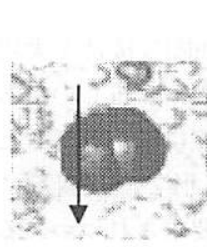

(a) $2 \mathrm{pcs}$

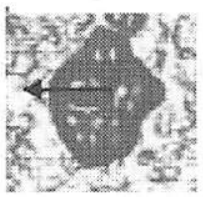

(d) $9 \mathrm{pcs}$

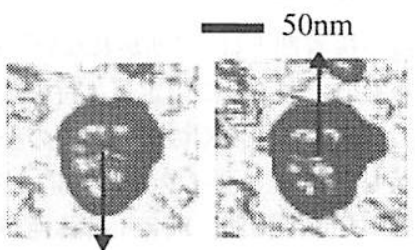

(b) $5 \mathrm{pcs}$

(c) $7 \mathrm{pcs}$

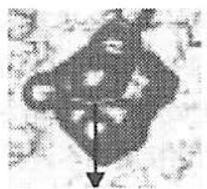

(e) $10 \mathrm{pcs}$

(f) 13 pcs

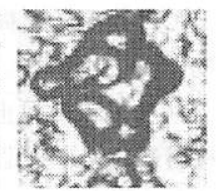

図 6 Separation of polymer aggregate.

有効性を紹介した。今後, 様々なナノスケールデバイス の開発および実用化が加速されるが，付着性および凝集 性の解析は重要な位置づけよる。今後の接着分野にお ける基礎的なデー夕蓄積が望まれる。

謝辞 本研究は, 澤永裕司氏, 丹治隆志氏, 平野正人氏 らのご協力による。ここの謝意を表する。また，本研究 の一部は, 日本学術振興会科学 研究費補助金 H13 15 年度基盤研究（C） 13650373, H16 年度基盤研究（B） 16360171 , および, 文部科学省 科学研究費補助金 H16 年度萌芽研究 16656105 の補助を受けて行われた。 